\title{
Esquimalt: An Outpost of Empire in the Great War
}

\section{Jan Drent}

Jusqu'à présent, le rôle de la côte ouest canadienne dans la guerre économique mondiale livrée par la Grande-Bretagne contre l'Allemagne impériale de 1914 à 1918 a été peu étudié. Tout au long de la Grande Guerre, les croiseurs et croiseurs marchands armés de la Marine royale ont maintenu un blocus ininterrompu au large des ports de l'Amérique centrale et de l'Amérique du Sud. Ils étaient appuyés par la base des Forces canadiennes à Esquimalt, la seule base de la Marine royale dans le Pacifique de l'Est. Le présent article traite de l'emploi du blocus et $d u$ fonctionnement $d u$ petit arsenal maritime d'Esquimalt comme rouage dans la guerre maritime mondiale de la Grande-Bretagne.

The distant blockade that effectively strangled imperial Germany's overseas commerce between 1914 and 1918 included a continuous presence by the Royal Navy along the Pacific coast of South America. The cruisers and armed merchant cruisers (AMCs) involved were supported from Esquimalt in British Columbia, the only base in the eastern Pacific available to the British. Esquimalt's roles in underpinning a close watch over enemy merchant ships in South American ports, and as a cog in gathering intelligence to support global economic warfare, have previously received little attention. How did the blockading vessels operate and remain at sea for weeks at a time? Accounts about Canada's Pacific coast during the First World War have focussed mostly on the dramatic defensive measures in the opening weeks of the conflict to counter the possibility that German warships known to be in the Pacific would appear off the northwest coast. These included the acquisition of submarines, and operations by Canadian and Allied warships in local waters and the northeastern Pacific. ${ }^{1}$ This account of Esquimalt's development up

\footnotetext{
${ }^{1}$ Gilbert Tucker, The Naval Service of Canada (Ottawa: Queen's Printer 1952), 1:160-161; William Johnston, William Rawling, Richard Gimblett, and John MacFarlane, The Seabound Coast (Toronto: Dundurn Press, 2010); Michael Hadley and Roger Sarty, Tin Pots and Pirate Ships (Montreal and
} The Northern Mariner / Le marin du nord, XXIX, No. 3 (Fall 2019), 233-254 
to 1914 and its role supporting the wartime blockade is based on ships' logbooks ${ }^{2}$ and reports of proceedings, ${ }^{3}$ contemporary naval records recently catalogued by the Maritime Museum of BC, and other sources.

British Columbia's colonial development had been as an imperial outpost rather than the result of westward expansion from central Canada. A flood of immigration to the west coast at the turn of the century had reinforced connections with Britain. ${ }^{4}$ The population of BC had more than doubled between 1901 and 1911 to 392,480 from 178,657 . The largest portion of this rapid growth, 38 percent, were new arrivals from the British Isles and possessions, while immigration from other parts of Canada contributed 32 percent. Fully 35 percent of Victoria's population of 32,000 in 1911 had been born in the UK; an additional 3 percent originated in other British possessions. (Interestingly, the figures for this cohort were also strong in Vancouver at 35 percent, and Toronto and Winnipeg at 30 percent. In Canada's largest and most cosmopolitan city, Montréal it was only 9 percent..$\left.^{5}\right)$ In 1914 the Royal Canadian Navy was, thanks to political indifference, an aspirational entity unable to man even one of its two cruisers. The recent flood of immigration included naval veterans who were providentially available when the RCN expanded to meet wartime requirements. The officers of HMCS Rainbow, Canada's obsolescent west coast cruiser, were breezily described by one of HMS Kent's officers in May 1915 as a "nondescript crowd of retired RNR farmers from the backwoods" but they did the job.

\section{The West Coast Infrastructure}

Esquimalt, at the southeastern tip of Vancouver Island is on the Strait of Juan de Fuca, the main sea route from the Pacific to Vancouver on the mainland and

Kingston: McGill-Queen's University Press), 1991; Marc Milner, Canada's Navy, The First Century (Toronto: University of Toronto Press, second edition 2010).

2 Digitized logbooks for all RN vessels in the eastern Pacific at www.naval-history.net, accessed between 1 June and 1 September 2018, are the result of a remarkable project by volunteers under the University of Oxford's Zooninverse project and the UK Meteorological Office to transcribe records of weather and other information from Great War naval logbooks.

${ }^{3}$ Monthly reports of proceedings (ROP) submitted by commanding officers are at the UK National Archives.

4 British historian Avner Offer observed that more than 5 percent of the population of the British Isles "left for good between 1900 and 1914." Avner Offer, The First World War: An Agrarian Interpretation (Oxford: Oxford University Press, 1989), 121.

5 Figures derived from The Census of Canada vol I, Table XXI (Ottawa: Dept of Trade and Commerce, Census and Statistics Office, 1912) and Tables XX and XXVI, vol II (1913). The overall population of Canada had increased by 34 percent between 1901 and 1911; immigration from Britain and British Possessions accounted for 22 percent and births in Canada to 52 percent.

${ }^{6}$ Thomas Benjamin Dixon, The Enemy Fought Splendidly Being the 1914-1915 Diary of the Battle of the Falklands \& its Aftermath by Surgeon T.B. Dixon of HMS Kent. (Poole: Blandford Press, 1983), 75. Dixon was a recently-commissioned 28-year-old RNVR junior surgeon. Kent socialised with Rainbow while coaling in 1915 on the Mexican coast. He wrote that "The Rainbow included old friends for several of our officers. They gave us much information on Esquimalt, and loaded us with the loan of tennis racquets, golf clubs, rods, etc." 
terminus of the main Canadian transcontinental railroad, and Puget Sound in Washington State. Its sheltered location and deep water make it a much better harbour than adjacent Victoria whose origins were as a Hudson's Bay post that took advantage of a location that was already a key seasonal indigenous trading site. Esquimalt became the North American base for the RN's Pacific station in the mid-nineteenth century as British warships were drawn north from their earlier base at Valparaiso when what would become British Columbia began its colonial development in the shadow of American westward expansion. These Victorian warships asserted colonial and later Canadian sovereignty along the long coasts of what would become BC. Charting the waters enabled commercial shipping in what evolved as Canada's western gateway. Eventually Esquimalt was formally designated as the Pacific station headquarters. A basic infrastructure of storage buildings and workshops had its beginnings in $1862 .^{7}$ Because its location was remote from important trade routes it was not developed as a major base. As part of imperial retrenchment at the start of the twentieth century the RN's Pacific station was formally closed in $1905 .{ }^{8}$ Canada had agreed to maintain the facilities, store fuel and supplies for the RN and permit it to use workshops and tools when custody of the naval dockyard was transferred in November $1910 .{ }^{9}$ Two small British warships, the sloops Algerine and Shearwater, both with crews of about 130, continued to be based at Esquimalt to fulfil imperial commitments to share Bering Sea seal hunting patrols with Russia, the USA and Japan. ${ }^{10}$ George Phillips, an Admiralty civil servant in charge of the dockyard lands and buildings, had transferred to Canadian service in $1910 .{ }^{11}$ When war came just over four years later the dockyard was supporting a variety of government vessels: the cruiser HMCS Rainbow which had been quiescent operationally because it was short of crew, the two RN sloops, the hydrographic survey ship Lillooet, four fisheries patrol vessels - the brand new Galiano and Malaspina, and the small Newington and Restless -

\footnotetext{
7 The yard was modernized after the graving dock was completed in 1887 with brick buildings replacing wooden structures. Jonathan Coad, Support for the Fleet: Architecture and engineering of the Royal Navy's Bases 1700-1914 (Swindon: English Heritage, 2013), 274.

${ }^{8}$ Barry Gough, Britannia's Navy on the West Coast of North America 1812-1914 (Victoria, Vancouver and Calgary: Heritage House, 2016),301.

9 Tucker, 160-161.

10 British warships had been involved policing the fur seal fishery since the 1880 s, initially in reaction to aggressive US actions against Victoria-based sealing vessels. They later supported efforts negotiated with the US government to mitigate conflicts between American, Russian, Japanese and Canadian fur sealing vessels. Progressive decimation of the seal populations resulted in the North Pacific Fur Seal Convention of 1911, the first international agreement to preserve wildlife. Don MacGillivray Captain Alex MacLean Jack London's Sea Wolf (Vancouver: UBC Press, 2008) 44,80,99,103; Gough 298. In 1914 the two British sloops along with US, German, and Japanese warships were off the west coast of Mexico in case internal strife threatened foreign lives or property. Canada agreed to substitute HMCS Rainbow for the Bering Sea commitment that August, which is why her complement had been brought up to strength by sending crew across from Halifax and out from the UK. Gough, 298.

${ }^{11}$ Barry Gough and John Greenhouse, "George Phillips, Vilhjalmur Stefansson, and Supplying the Canadian Arctic Expedition 1913-1918," Polar Record 31 (176) (January 1995), 38.
} 
plus Estevan, a new lighthouse tender. The dockyard had also undertaken other tasks such as preparing the 1913 Canadian Arctic Expedition. This was a crash project that involved outfitting the venerable wooden brigantine Karluk and organizing stores to be carried north by three support vessels.

Although it would prove too small for all but one of the RN vessels refitted in Esquimalt between 1914 and 1918 the government-owned graving dock adjacent to the dockyard was a major strategic asset. When opened in 1887 it had been large enough to take warships and freighters of medium size. ${ }^{12}$ Local capacity for complex repairs had however been limited prior to 1914: when Algerine lost a propeller in heavy weather in 1913 a replacement had to be manufactured in Seattle and fitted there. ${ }^{13}$ Shortly before war came the BC Marine Railway Company, a small repair and building yard at the eastern end of Esquimalt harbour, was bought by Sir Alfred Yarrow, the driving force behind an innovative warship building yard in Scotland which also produced complex turbine machinery. The new management trio was a long-time Yarrows manager, Sir Alfred's twenty-two-year-old son Norman as his understudy, and a company engineer, Edward Izard, aged twenty-six. ${ }^{14}$ Their arrival and expertise would prove fortuitous when they undertook complex repairs on warships during the war.

\section{The Imperial Pacific Cable and West Coast Radio Stations}

New technologies enabled rapid worldwide communications. A transpacific cable from Vancouver Island to Australia was completed in $1902 .{ }^{15}$ This was the final length in the "All Red Route" that provided communication between the dominions and colonies of the British Empire. It was an essential link in the Admiralty's worldwide communications and intelligence gathering networks.

Radio was another new technology coming into service just prior to the Great War. ${ }^{16}$ A chain of stations had been built by the Marconi Company in eastern Canada starting in 1904 and were operated under contract. By contrast the government built and operated its own stations on the west coast. The first was on Gonzales Hill in Victoria in 1906; by 1912 there were ten stretching up the outer coast, and

\footnotetext{
${ }^{12}$ Its length is $146 \mathrm{~m}$ (481 feet). It was intended to be large enough for the most recent RN armoured cruisers at the time, the 7,400-ton HMS Nelson and HMS Northampton. Major F.V. Longstaff, Esquimalt Naval Base (Victoria: Victoria Book \& Stationary Co.:1941), 37. By 1914, less than thirty years later, armoured cruisers were one third larger.

${ }_{13}^{13}$ G.W. Taylor, Shipyards of British Columbia (Victoria: Morris Publishers, 1986), 66.

${ }^{14} \mathrm{Ibid}, 67-69$. Alfred Yarrow's decision to buy in Esquimalt was influenced by Canadian government plans to create a much larger graving dock because the existing one was too small to handle the large new ships involved in growing Pacific trade. This larger graving dock was built after the war and opened in 1926. Its length is a massive $357.5 \mathrm{~m}$ (1,173 feet).

${ }^{15} \mathrm{R}$. Bruce Scott, Gentlemen on Imperial Service: A Story of the Trans-Pacific Telecommunications Cable, (Victoria: Sono Nis Press, 1994),22-25. This Pacific cable, replaced by fibre optic cable, was withdrawn from service in 1964.

16 This section draws on Larry Reid An Early History of the West Coast Radio Service (1989) accessed 15 May 2017 at https://www.roughradio.ca.
} 
between Vancouver Island and the mainland as far as Haida Gwaii and Prince Rupert. ${ }^{17}$ The range of radio reception and transmission was limited to hundreds of nautical miles ${ }^{18}$ which meant that communication with warships in distant areas depended on cable connections when they reached ports. Transmission ranges were also limited: Rainbow's at the start of the war was only 200 miles at night when propagation conditions were most favourable. ${ }^{19}$ Wireless was not widely fitted in cargo ships until during the war; ${ }^{20}$ vessels would come close enough to coastal stations to communicate by signal flag or read storm warnings. The Canadian government Wireless Telegraphy Branch became part of the new Department of the Naval Service in 1910. Most of the operators were recruited from the British telegraph services. Within short years operating hours were extended, resulting in an extensive recruiting effort in Britain between 1911 and 1914 to give most stations four operators. The Naval Service assumed control of all radio stations on 2 August 1914, two days before Britain declared war on behalf of the dominions. ${ }^{21}$ The radio operators were enrolled in the Royal Naval Canadian Volunteer Reserve in 1916 as "Special Wireless Telegraphy Operators" and provided with uniforms. ${ }^{22}$

\section{The Naval Intelligence Centre Esquimalt}

For the British the key to implementing economic warfare was gathering information and tracking merchant ship movements. Since 1902 the Admiralty had planned how to create a global intelligence network of regional intelligence centres, ${ }^{23}$ one of which was Esquimalt. As war approached the newly-created Canadian naval service prepared a naval intelligence system as part of the imperial structure. It arranged with London to have the Canadian regional centres report to both it and the Admiralty. ${ }^{24}$ A directive in December 1913 from the department described the Canadian naval intelligence system as decentralised, with each

17 Ibid.

${ }^{18}$ HMS Kent reported establishing contact with Estevan Point on the west coast of Vancouver Island at a range of 1,140 nm in May 1915; earlier that year HMS Newcastle reported daytime ranges of 600nm with Gonzales and Estevan. Naval Intelligence Officer Reports of Proceedings for Weeks of 23 April and 28 May 1915. Maritime Museum of BC (MMBC) ACC 2017.001. These will be cited as Weekly ROP.

19 Tucker, 264. Atmospheric conditions affected ranges: in May 1916 traffic from Rainbow, operating off Central America, was received at a range of 1,400 nm. Weekly ROP Week ending 19 May 1916.

20 In 1915 UK legislation required all merchant ships over 3,000 tons to be equipped with radios; other nations soon prescribed similar regulations. Reid, 13.

21 Tucker, 213.

22 File folder "Correspondence with the Radio Telegraph Service", MMBC ACC 2017.R.001; they are shown in the RNCVR Officers section of the Canadian Navy List September 1916 (Ottawa, 1916), 34-37.

23 Matthew Seligmann, The Royal Navy and the German Threat 1901-1914 (Oxford: University Press, 2012),109-131; Nicholas Lambert, "Strategic Command and Control for Maneuver Warfare: Creation of the Royal Navy's "War Room" System 1905-1915," Journal of Military History 69 (April 2005), 361-410.

24 Johnston, Rawling et al., 278. 
of its three centres (Esquimalt, Halifax and Ottawa, covering the Great Lakes) collecting and distributing information in its own area. The coastal radio stations were to intercept radio traffic by warships and report to the intelligence centres on the movements of British and foreign naval vessels. ${ }^{25}$ As part of the worldwide Admiralty system Esquimalt's "area of observation" was the northeast Pacific.

When Britain declared war for the empire on 4 August the naval service was able to call up RN veterans living in Canada. Frederic William James, a forty-six year old lieutenant only just arrived in Vancouver from the UK, was appointed as Naval Intelligence Officer Esquimalt on August $8 .{ }^{26} \mathrm{James}$ had spent twenty-seven years at sea, half in the merchant service where he qualified as master mariner and the following half in the $\mathrm{RN}$ where he served as a navigation specialist. Most of his RN service had been at sea but he had also been harbourmaster in Hong Kong and thus had wide experience. James' job title evolved from "Naval Intelligence Officer" to "Canadian Staff Officer" by 1916. He reported to the department in Ottawa as the west coast link with the Admiralty's worldwide intelligence system. He was in regular contact with his counterpart in Kingston, Jamaica, (changed in November 1916 to Callao, Peru), ${ }^{27}$ British consular officers and agents in ports in the eastern Pacific and, after 1917, with US west coast authorities. James was given the temporary rank of commander and produced the first of his weekly reports of proceedings to the senior officer in the dockyard on 22 August. They provide a window on how the RN's global information-gathering system functioned at the dawn of rapid communication by radio and cable.

\section{The Eastern Pacific in a Global Maritime War}

By 1914 the world's industrialised economies were mutually dependent. The importance of international trade by sea was underlined by its 63 percent growth in value between 1904 and 1912. ${ }^{28}$ British shipping, 45 percent of the world's tonnage in 1914, was dominant as was London for financing of global trade. The pound sterling was the international currency benchmark. Germany had the second

\footnotetext{
25 "Instructions for Collection of Naval Intelligence" Department of the Naval Service 17 December 1913 superseded an earlier set of instructions dated November 1911; MMBC ACC 2017.R.001. Halifax already had a Naval Intelligence Officer in December 1913, but on the west coast this duty was assigned to the Commander in Charge Esquimalt. The archival records show that the coastal stations monitored naval and merchant ship traffic throughout the war, but not find any startling information.

26 Frederic James Fonds, MMBC. James had retired in 1910 and had received a letter from the Admiralty on 22 July 1914 apparently while still in England, granting permission to live abroad but was required to keep the Admiralty supplied with his address. In those simpler times Vice Admiral Kingsmill, Director of the Naval Service Ottawa, sent a CP telegram on 8 August 1914 addressed simply to "Lieut F James, RN, Vancouver" signed CE Kingsmill that told James to report to Esquimalt immediately.

27 A new Naval Intelligence Centre was established in Callao in November 1916 after experience showed that coordination on the west coast of South America from Kingston was unwieldy. HMS Lancaster ROP, 25 November 1916, TNA, ADM 137/763, 167,195.

${ }^{28}$ S.G. Sturmey, British Shipping and World Competition (London: The Athlone Press, 1962), 21.
} 
largest merchant fleet with 11 percent of total tonnage, but did not play a key role in international finance. ${ }^{29}$ Both Britain and Germany were dependent on imports of raw materials and food. ${ }^{30}$ Both governments had studied the vulnerability of their own and each other's economies if shipping was cut off and had planned for economic warfare. Shipping was vulnerable to interdiction in focal points where ocean routes converged such as off San Francisco or the entrance to the Panama Canal that opened in August 1914. The Germans anticipated that their merchant fleet would be driven off the oceans by the powerful RN but planned to attack enemy trades in the focal areas with warships and armed merchant vessels. Imperial Germany attempted to maintain imports, particularly from the United States, through neutral neighbours which remained open to ocean trade.

By monitoring seaborne imports by neutral European countries the British aimed to restrict these to only what was required for their domestic economies. Commander James received a directive from the Admiralty in February 1915 to "treat all neutral vessels as suspicious." ${ }^{31}$ His reports reflect how an extensive reporting net in US west coast ports tracked outgoing cargoes. For example, in January 1915 there was a report apparently based on mail intercepted between a Seattle firm and an agency in Vienna about how they were moving supplies through Copenhagen, and in American vessels through Bremen. In March the vice consul Tacoma reported on a Danish freighter that had cleared Seattle with supplies for Germany. ${ }^{32}$

For Britain preserving existing trading patterns was essential for two key reasons: to maintain imports but also to sustain the substantial income earned by providing the financial underpinnings for the global trading system. At the outbreak of war imports to the UK from Vancouver and Puget Sound ports of grain, lumber and salmon were not of major importance. ${ }^{33}$ Voyages from the Pacific Northwest involved much longer hauls than from the eastern side of North and South America. The dramatic role of the Panama Canal in shortening voyages was reflected in January 1916 when Commander James noted that a collier, that had just sailed could reach now Britain in four weeks via the canal but would require seven if going by the Magellan Strait at the bottom of South America. ${ }^{34}$ Imports from the west coast of South America were less important for Germany and Britain than those from the Atlantic side. Three cargo flows from the Pacific were however strategically important: Bolivian tin, Chilean copper - and nitrates. ${ }^{35}$ Until 1914 Chile produced almost 80 percent of the world's nitrates, the most important source of fertilisers and explosives. Germany was in fact the leading importer of

\footnotetext{
29 Thorston Rinman and Rigmor Brodefors, The Commercial History of Shipping (Gothenburg: Rinman \& Linde AB, 1983), 73-74.

${ }^{30}$ Offer, $1-5$

${ }^{31}$ Weekly ROP Week ending 12 February 1915.

32 Weekly ROP Weeks of 29 January and 19 February 1915.

${ }^{33}$ Ernest C. Fayle, Seaborne Trade, (London: John Murray, 1920), 1:156

${ }^{34}$ Weekly ROP Week ending14 January 1916.

${ }^{35}$ Fayle, 1:156.
} 
nitrates before the war; the loss of this trade was a severe blow for its agriculture and spurred the development of synthetics. The UK greatly increased its imports of Chilean nitrates during the war; the portion used for military purposes mushroomed to 80 from 20 percent. ${ }^{36}$

When war erupted German warships already in the Pacific briefly disrupted British shipping including the nitrate trade. The cruiser Leipzig had been one of the warships from several navies protecting international interests on the Mexican coast in late July and now came as far north as the shipping focal area off San Francisco. She loitered offshore 11-17 August, effectively blockading twenty-five British freighters in port, ${ }^{37}$ and finally coaled there. The story of how Rainbow had been ordered south to "guard trade routes North of Equator" on 3 August, even before war was declared is well known. ${ }^{38}$ Japan entered the war on 23 August and its armoured cruiser Idzumo arrived in Esquimalt on the $25^{\text {th }}$ from Mexico $^{39}$. The cruiser HMS Newcastle came across the Pacific from the China Station, reaching Esquimalt on 30 August. ${ }^{40}$ Japanese warships were welcome allies and were provided with intelligence, coal and maintenance in Esquimalt. A Japanese naval officer joined the naval intelligence cell in October. ${ }^{41}$ The Japanese warships worked the coastal radio stations and passed traffic on to more distant British warships. A German squadron under Count von Spee that had been based in Tsingtau, China, moved across the Pacific and defeated a British force off Coronel, Chile on 1 November. The elusive von Spee in fact sank few ships but establishing his location was a huge challenge in the vastness of the Pacific. Efforts to counter this transitory threat to shipping eventually involved several British, Australian and Japanese warships and supporting colliers. His cutting of the trans-Pacific cable linking Vancouver Island and New Zealand on 7 September underlined its strategic importance and hampered the British search. An RN force had already

\footnotetext{
36 Bastias S Manuel, "Nitrate," International Encyclopedia of The First World War, managed by Freie Universität Berlin 2014 -10-08; https: encyclopedia. 1914-1918-online-net, accessed 15 May 2017.

37 Fayle, 1:163-4.

38 Tucker, 263-271; Johnston, Rawling et al., 230-241.

39 Armoured cruisers displaced around 10,000 tons in contrast to light cruisers of around 5,000 tons. The heaviest guns mounted by both types were typically $15 \mathrm{~cm}$ ( 6 inch). Yarrows immediately did maintenance on her main engines, and in September Idzumo returned for more repairs. E. Izard recalled how the Japanese paid for the work in \$1,000 bills with the balance in silver dollars. "History Project Yarrows" annotated by E. Izard, 25 August and 13 September 1914, MMBC L 884.6.1 a E. Izard Fonds.

${ }^{40}$ The Admiralty had on 11 August ordered the C-in-C China to send a light cruiser to the west coast via Yokohama; Sir Julian S. Corbett, Naval Operations, (London: Longmans, Green \& Co, 1920), 1:146. In 1908 when reducing forces in the Pacific and consolidating the remainder in China the Admiralty had projected that it would take twenty days to despatch a cruiser from Hong Kong to the west coast; Gough, Britannia's Navy, 303.

${ }^{41}$ Japanese naval liaison officers were part of James' staff from October 1914 to October 1915 when Japanese ships left the coast. Their co-operation was described as "most useful." Weekly ROPs, 30 October 1914 and 12 February 1915; Letter from Admiral Superintendent HMC Dockyard Esquimalt 4 July 1917, LAC RG 2411902 AE 6-10-1 "Relationships with Imperial Japanese Navy.”
} 
destroyed the German cable station on Yap as early as 12 August, ${ }^{42}$ depriving von Spee of intelligence relayed from China. SMS Geier, an elderly small cruiser had been on passage to the German base in North China when war came and had then not been able to catch up with von Spee's squadron. Geier eventually reached Honolulu in mid-October and was along with her collier interned by the Americans on 8 November ${ }^{43}$ Von Spee's force was annihilated off the Falklands in December. Coordination of operations in the eastern Pacific between British and Japanese warships appears to have been limited later in the war. ${ }^{44}$

\section{Royal Nay Presence off South America}

Forty Central Powers' steamers and sixty sailing vessels ${ }^{45}$ were caught in South and Central American and US west coast ports ${ }^{46}$ when war came in August 1914. A further eight were in Hawaii. Once the threat posed by German warships in the eastern Pacific had been eliminated the RN established a continuous presence of cruisers and armed merchant cruisers (AMCs) ${ }^{47}$ off South America. It prevented enemy merchant ships from leaving neutral harbours and monitored neutral vessels bound for Europe. After the US entered the war in April 1917 German and neutral ships in the Philippines, Hawaii and American ports were commandeered by the US. Peru remained neutral but severed diplomatic relations in October 1917 and turned the German merchant ship in its ports over to the US.

For the first two years the blockading force was two cruisers and two AMCs; during the next eighteen months the combination was three AMCs and a single cruiser, and dwindled to a single cruiser and one AMC during the final six months ${ }^{48}$ Their movements were mostly controlled by the senior cruiser, normally

\footnotetext{
${ }^{42}$ This included Newcastle which was then ordered to Esquimalt.

${ }^{43}$ Wikepedia.de: SMS Geier accessed 15 April 2019; Phillip G. Pattee, At War in Distant Waters (Annapolis: US Naval Institute Press, 2013), 170.

${ }^{44}$ On 5 April 1916 Newcastle, as senior ship coordinating RN operations in the eastern Pacific, asked Esquimalt from S America whether there were any Japanese warships on the west coast and about their anticipated movements. Esquimalt replied that it had was unaware of any. Weekly ROP Week ending 7 April 1916.

45 Harold D. Huycke To Santa Rosalia Further and Back (Newport News: The Mariners Museum, 1970) tells the story of sixteen German sailing ships trapped in Santa Rosalia in Baja California 1914-18.

46 Fayle, 2:178. According to Fayle, 1: 198 More than 670 German and Austrian merchant ships, almost half of the Central Powers' total merchant fleets with a total tonnage of 2,750,000 as well as seventy-two sailing ships, remained in neutral ports worldwide after the outbreak of war.

47 These were 12,000 to 15,000 - ton converted intermediate size recently-built passenger liners with speeds of fifteen to eighteen knots. The 1914-18 Navy Lists show that they were commanded by RN captains or commanders. Richard Osborne, Harry Spong and Tom Grover, Armed Merchant Cruisers 1878-1945 (Windsor: World Ship Society, 2007), 42-43 explains that these commanding officers were recalled from recent retirement. The remainder of the crews were a blend of merchant service officers and ratings serving in the RNR under "T 124" agreements which were modified civilian employment articles of agreement and $\mathrm{RN}$ pensioners and reservists.

48 Cruisers: Newcastle and Kent, 1914-16; Lancaster 1916-19; AMCs: Orama 1914-15, Otranto 1915-18, Orbita 1916-18, Avoca 1916-18. Otranto had been off South America in October 1914
} 


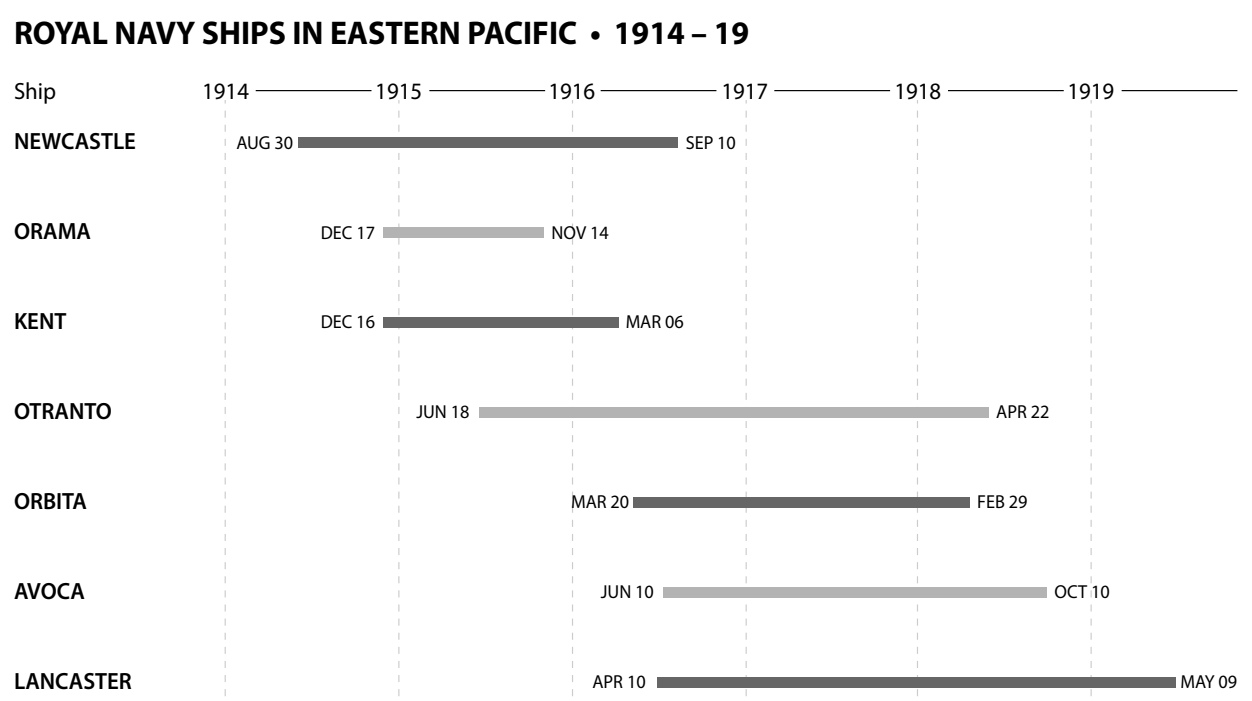

\section{Based on logbooks at www.naval-history.net}

far from Canadian waters in the eastern Pacific. On occasion the Admiralty ordered movements directly because it had an overall intelligence picture ${ }^{49}$ Rainbow contributed by doing three patrols to Mexico and Central America: FebruaryMarch in 1915, and February- May and August - December 1916), operating as far south as Panama ${ }^{50}$ Rainbow seized two small vessels under German ownership off Mexico in April 1915, Oregon and Leonor. These were brought to Esquimalt as prizes. ${ }^{51}$ The RN system of gathering and reporting intelligence in South American ports about cargo movements apparently obviated a need to board neutral merchant ships bound for Europe. The logs record only a handful of boardings. The British interpreted international law aggressively. Lancaster seized the freighter Edna, then registered in San Francisco but with a murky former German ownership, off Chile in March 1916. A prize crew took the ship to the Falklands; she served the

as part of the British force searching for a German squadron but had escaped during the disastrous Battle of Coronel and returned to the UK to refit after helping in the search for von Spee. A fifth AMC, Celtic, operated along the Chilean coast as far north as Valparaiso for eighteen days in 1915. Her log suggests her main function was to replenish Newcastle, Kent and Orama with stores and ammunition. The small AMC Ophir arrived from the China Station in September 1918 when Lancaster went north to refit and covered the eastern Pacific until December.

49 The commanding officer of Lancaster was given the appointment of commodore in 1917, designated Rear Admiral South Pacific and promoted to rear admiral in April 1918.

${ }^{50}$ Johnston, Rawling et al., 373-4, spotlights another instance of how relationships between imperial authorities and the RCN required improvement: Rainbow's patrols had been arranged with the Admiralty through NSHQ but after her first one in 1915 the Admiralty observed that she had not kept the senior officer in the area, Captain Powlett of Newcastle sufficiently informed of her movements. ${ }^{51}$ Johnston, Rawling et al., 370-2; HMCS Rainbow ROP May 1916, TNA ADM 137/ 762, 431-436. 
rest of the war under the British flag..$^{52}$ In February 1917 Otranto intercepted a Chilean steamer in international waters off Peru to capture Ernst Krause, an agent for a German shipping company in Callao. He was transported to the Falklands and in August ended up in an internment camp in South Africa. ${ }^{53}$ There was at least one occasion when an RN vessel, in this case HMS Avoca, landed an armed party to investigate the seizure of British property in Salina Cruz, Mexico in July 1916 because of local disturbances. ${ }^{54}$

The logbooks show that the blockading ships operated close offshore along a 2,400 $\mathrm{nm}(4,444 \mathrm{~km})$ track from Santa Elena in Ecuador to Valdivia in Chile,

\section{THE VOYAGES OF HMS AVOCA - March 1916 to March 1917}

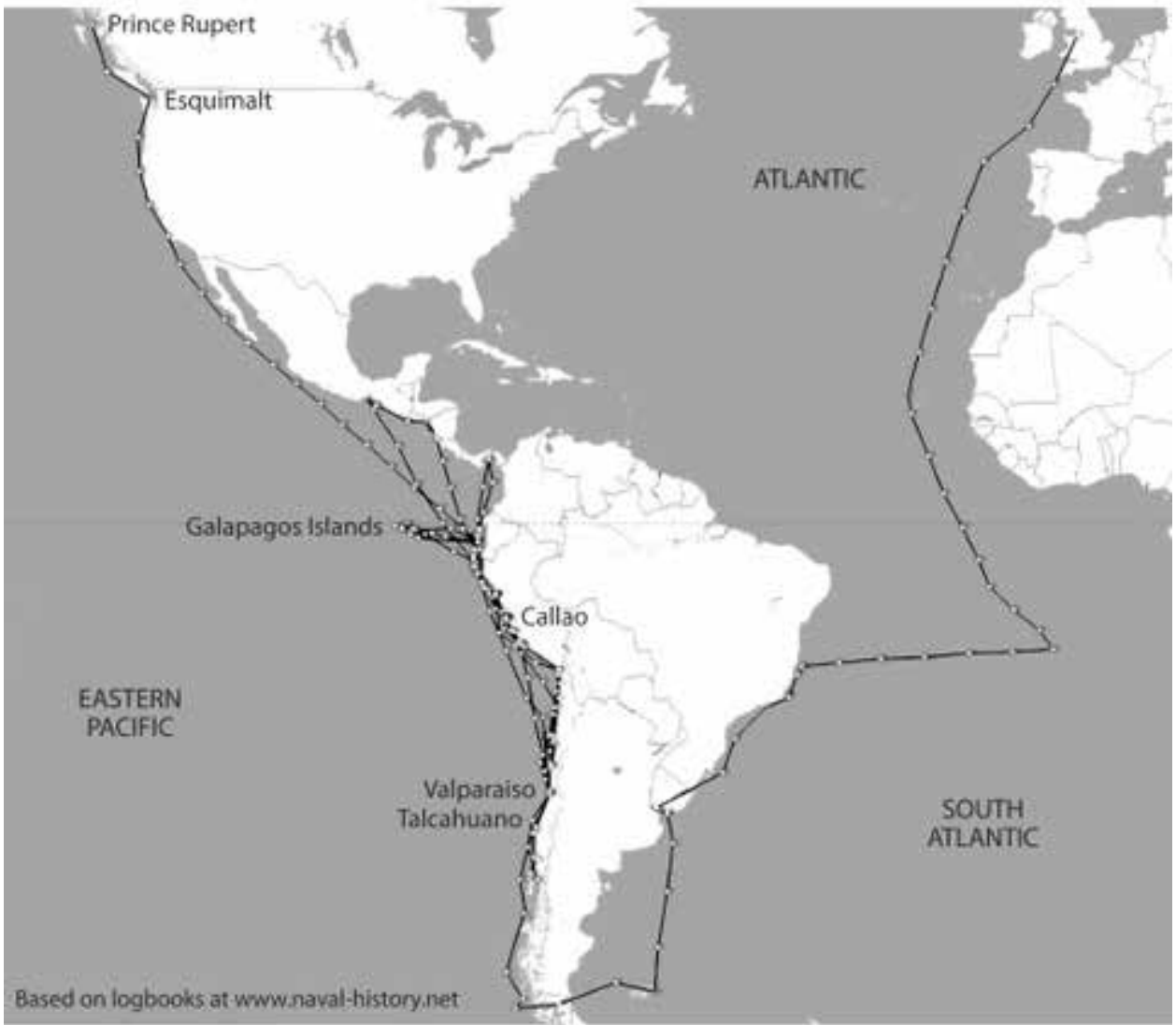

THE DOTS ARE PLOTS OF NOON POSITIONS. NOTE HOW THE TRACKS HUG THE S. AMERICAN COASTS;

THOSE OF THE OTHER BLOCKADING CRUISERS AND AMCS 1914-18 WERE SIMILAR.

\footnotetext{
${ }^{54}$ Osborne et al, 95; Avoca's log 4-8 July 1916 does not record landing the armed men but its laconic entries hint at unusual events: 4 July (date of arrival): "Hands employed... building sandbags around wheelhouse"; 5 July "seaboat left for American cruiser...returned; Captain left ship...returned"; 6 July; "Mexican gunboat entered breakwater; American cruiser Albany entered harbour, Japanese SS Seiyo Maru entered harbour"....8 July: "Mexican gunboat entered harbour and proceeded inside.... British Consul came on board...left ship; Heave up Anchor."
} 
and occasionally off Central America. ${ }^{55}$ The tracks for Avoca shown below are typical. This operating area was favoured by generally moderate weather as gales are infrequent even in the southern winter. ${ }^{56}$ Certain bays and roadsteads were visited regularly; the ships anchored overnight or for a few hours frequently, and occasionally for one or two days, to conserve fuel. Four of these anchorages could be use without infringing neutrality as they were outside the three-mile territorial sea; others were remote and "fairly safe from discovery." 57 The cruisers and AMCs were sometimes together at anchorages; now and again operated in company; but for the most part worked their way up and down the coasts singly. They were replenished at these anchorages by colliers that had come all the distance from Britain with Welsh coal. ${ }^{58}$ Colliers and merchant fleet auxiliaries brought out naval stores (i.e. standard spare parts, consumables such as cleaning materials, etc.). Fresh provisions were provided by commercial lighters off major ports. Colliers or another naval vessel were used to tow targets for periodic guns' crew firings.

The patrolling vessels regularly visited principal ports such as Valparaiso and Callao to pick up naval messages sent out by cable circuits to British consuls. (British warships could not be reached by radio broadcasts from shore station networks until the early 1930s.$^{59}$ ) Cruisers and AMCs anchored or moored to buoys when visiting ports including Esquimalt; they berthed alongside very rarely at coaling docks. The armed merchant cruisers had good endurance, having been built for the UK to Australia and South America runs. They generally had to coal only once a month, while the cruisers coaled roughly every ten days. ${ }^{60}$ Coaling was a gruelling all hands evolution ${ }^{61}$ and was challenging in exposed anchorages. The commanding officer of HMS Newcastle observed "the difficulty of coaling in open waters is at times very great." ${ }^{62}$ Taken together the cruisers and AMCs in the eastern Pacific would have coaled hundreds of times. The logbooks record few mishaps during coaling which attests to their operating proficiency. Orbita did

\footnotetext{
55 The digitized logbooks are accompanied by maps for each ship which track their movements based on noon positions.

56 South America Pilot, (Taunton: Hydrographer of the Navy, fifth edition, 1968), 3:30-35. Gales occur more than 20 percent of the time south of the normal operating area. The blockading ships recorded heavy weather when patrolling south of Cape Horn in April and May 1917 and off northern Vancouver Island during winter passages to Prince Rupert.

57 Rear Admiral Pacific ROP 9 March 1919 TNA ADM 1/8561/169, 10.

${ }^{58}$ In 1917 a collier left England every three weeks for the eastern Pacific. Commodore Commanding South Pacific Squadron ROP 11 November 1917, TNA ADM 137/764, 20.

59 Geoffrey Bennett, Coronel and the Falklands (London: Batsford, 1962) Appendix II, 1823 discusses the difficulties the Admiralty had communicating with ships off the west coast of S America between 1914 and 1918.

${ }^{60}$ Based on an analysis of the various ships' logs at www.naval-history.net.

${ }^{61}$ The logs show that coaling could on occasion extend over three days. Coaling, especially from a collier, was the subject of "near universal loathing" by sailors. Stephen Gray, Steam Power and Sea Power: Coal, the Royal Navy and the British Empire c. 1870-1914 (London: Palgrave, 2018), p. 171; "the most hated and filthy of tasks": Christopher McKee, Sober Men and True: Sailor Life in the Royal Navy 1900-1945 (Cambridge, Mass.: Harvard University Press, 2002),119.

${ }^{62}$ HMS Newcastle ROP 31 July 1916. TNA ADM 137/762, 132.
} 
collide with a collier anchored off Peru in darkness in February 1918, fortunately with no injuries. The collier subsequently sank under tow. ${ }^{63}$ Lancaster fought a coal fire in a collier's hold in the anchorage off Tongoy in Chile in February 1918. ${ }^{64}$

There were few distractions or opportunities for the ships' companies, which numbered roughly 2,200 men ${ }^{65}$ to experience a change of scene during their long months on board ${ }^{66}$ The AMC Otranto for example granted leave to senior crew members- chief petty officers and petty officers - only once during her first six months in the Pacific in 1915. In 1916 this group got ashore eight times over a six-month period, never for more than five hours. More junior crew members were allowed ashore for a single picnic and beach party. Overnight leave was however given to all ranks during refits and dockings in Esquimalt and Prince Rupert. By 1917 more generous shore leave was granted; in seven months underway all ranks from leading seaman and above received it on seven occasions. In 1918 during her final four months off South America, Otranto's leading seamen and above got ashore nine times. ${ }^{67}$ The senior officers reported frequently to the Admiralty about the hardship for their ships' companies of monotonous months underway and recommended involving Rainbow more regularly to enable RN ships to visit Esquimalt more often. ${ }^{68}$ While Esquimalt provided welcome respite for sailors some took advantage of opportunities to desert. ${ }^{69}$

The motives for keeping enemy shipping bottled up were twofold: to prevent cargoes from reaching the Central Powers, and to prevent German ships confined to harbour from turning themselves into raiders or becoming support ships for raiders already at sea. During the decade prior to 1914 the Admiralty speculated that German merchant ships might carry guns in their holds in peacetime to convert themselves or might be armed at sea by another vessel. ${ }^{70}$ In the event Germany was able to outfit only a handful of such raiders, in fact using guns transferred from warships rather than already on board; their effect was negligible. Indeed, by February 1915 the Admiralty had determined that none of the German armed merchant cruisers that had operated early in the conflict had armament on board at the outbreak of war. It concluded that the enemy merchant ships in neutral harbours

\footnotetext{
${ }^{63}$ The log also recorded the inevitable board of enquiry conducted by the flagship a few days later. HMS Orbita log, 7-25 February 1918.

${ }^{64}$ HMS Lancaster log, 5 February 1918.

${ }^{65}$ HMS Lancaster ROP 25 September 1916, ADM 137/763, 156.

${ }^{66}$ The logs record very infrequent sports' days on board, inter-ship boat pulling or sailing competitions.

${ }^{67}$ A change in commanding officer in September 1916 may have led to more generous short leave.

${ }^{68}$ For example, HMS Newcastle ROP 25 November 1915, TNA ADM 137/762, 215.

69 There were thirty-one desertions during Newcastle's visit in November. Ibid, 215. Lancaster reported forty-five absentees on leaving Esquimalt in September 1916, most of whom would become deserters. The comparatively high pay being offered for enlisting as a soldier was cited as one of the "many inducements" to desert in BC. HMS Lancaster ROP 25 September 1916, TNA 137/753, 135. 70 Seligmann, 27-45; Archibald Hurd, The Merchant Navy (London: John Murray, 1923),1:125-7 lists German merchant ships considered by the Admiralty at the outbreak of war as being capable of conversion to armed merchant cruisers. Forty-two were in overseas ports; none in the eastern Pacific. There were also sixteen in German ports.
} 


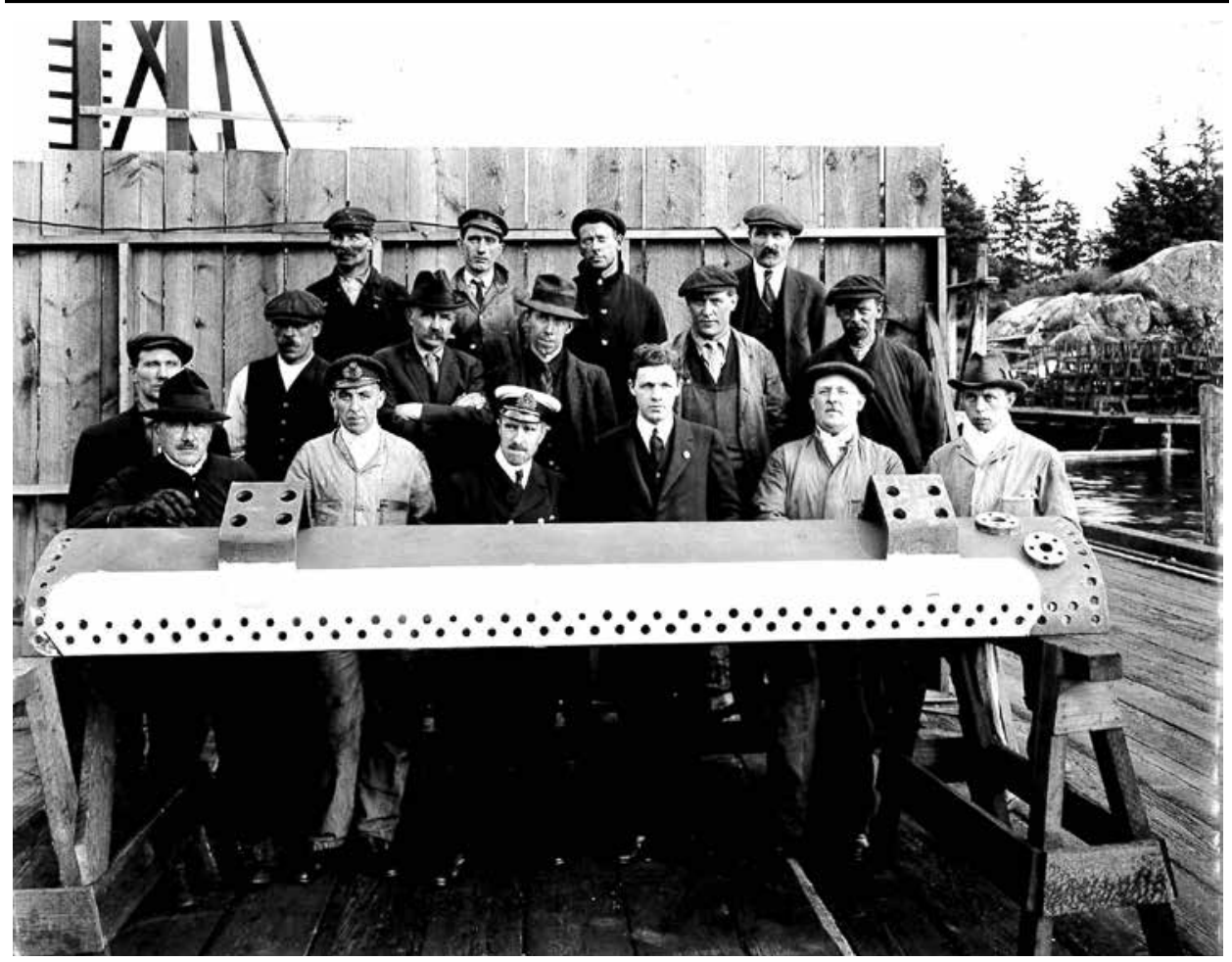

Supply Chain 1916 Style: Replacement wrapper plate for HMS NEWCASTLE boiler fabricated by Yarrows parent firm in in Scotand and shipped out with 12 fitters 1916. NEWCASTLE Engineer Officer third from left, Norman Yarrows fourth from left, Edward Izard extreme right. (Maritime Museum of British Columbia)

might break out to become support vessels for raiders but would not themselves take on this role..$^{11}$

The possibility that enemy commerce raiders might appear in the Pacific remained a threat. The German Navy had successfully sent out a second wave of converted merchant ships during the winter of 1916/17. ${ }^{72}$ The apparent disappearance of a freighter bound for San Francisco from New Zealand in June 1917 typifies how difficult it was to establish whether enemy raiders were present. In July 1917 Hong Kong advised the naval intelligence network that the British freighter Wairuna was overdue on a voyage from Auckland to San Francisco. On 29 July Commander

\footnotetext{
${ }^{71}$ Pattee, 189-90. However, a dismounted gun was found in September 1914 in the hold of a German merchant ship that had run aground off New Guinea, confirming pre-war suspicions about how merchantmen might arm themselves. Pattee, 151.

72 One of the trio, the converted freighter Möwe operated successfully in the Atlantic between November1916 and April 1917. Concerned about the weak defences of the important radio station in the Falklands the Admiralty ordered Lancaster to mount two of her fourteen $15 \mathrm{~cm}(6 \mathrm{inch})$ guns at Port Stanley. Newbolt,4:184. This became an epic operation with 100 sailors on drag ropes moving the heavy guns. HMS Lancaster log 16 January-3 February 1917; ROP 28 February 1917,237.
} 
James noted "Callao asks if there is any further news of Wairuna. Replied 'none.' Press reports vessel 30 days overdue on $25^{\text {th }}$ July, possibly disabled at sea, and search being made." In fact, Wairuna had been captured east of New Zealand eight weeks earlier on 2 June by the German raider Wolf, a seaplane-equipped converted merchant ship. ${ }^{73}$ The other raider to appear in the Pacific that year was Seeadler, a square rigger with an auxiliary engine under Count von Luckner that penetrated to the Pacific after operating for several weeks off Brazil. When in April 1917 the Admiralty believed that the raider was making for Cape Horn, Lancaster and the armed merchant cruisers Orbita and Otranto off the west coast of South America were ordered south to intercept. Avoca, an additional AMC that had just been drydocked in Prince Rupert was ordered south to search the Galapagos area, also without success. Given the fact that the searchers were limited to detecting an enemy only out to their visual horizons, and the vast area to be covered, Seeadler was able to avoid interception. ${ }^{74}$ Von Luckner operated in mid- Pacific for several months, sinking only three small American schooners ${ }^{75}$ but causing disruption; his ship was wrecked on a reef in early August. American historian Paul Halpern cites a later Admiralty study that most of the losses to raiders could have been prevented had a convoy system been in use..$^{76}$

The Germans like the British had prepared for wartime economic warfare and intelligence gathering. Paul Halpern has observed by that the imperial navy's Etappendienst (literally "Support Service") sought to overcome the problems caused by a lack of overseas bases. It placed retired naval officers in key ports overseas, created a network of reporting agents, and an organization to commandeer German merchant ships as supply vessels for commerce raiders. ${ }^{77}$ The Etappendienst organized replenishment by the freighter Amasis in the isolated Galapagos Islands in September for Leipzig on her way south from Mexico. Amasis then accompanied Leipzig southwards to Easter Island where they joined two other supply ships despatched to meet von Spee in remote anchorages on his way across the Pacific. The Etappendienst arranged subsequent replenishments at Juan Fernandez Island off Chile and after the Battle of Coronel, and a final operation at the southern end of Chile just before von Spee left the Pacific. Later German freighters were despatched to support the cruiser Dresden following her escape from the Battle of the Falklands in December, and the armed liner Prinz Eitel Friedrich that had operated briefly with von Spee and remained in the Pacific until early January $1915 .{ }^{78}$ These several merchant ships were among those trapped

\footnotetext{
${ }^{73}$ Her nemesis, SMS Wolf, was back in the Indian Ocean before a chain of losses could be connected to mines she had dropped off New Zealand. Wolf's seaplane had dropped a message on Wairuna's deck threatening to drop bombs. Newbolt, 4:218-220. After transferring her cargo of fresh meat, cheese, milk and coal Wolf sank the prize.

${ }^{74}$ Vessels of both sides also listened for radio transmissions by enemy ships.

75 Robin Bromby, German Raiders of the South Seas (Sydney \& Auckland: Doubleday, 1985),183.

${ }^{76}$ Paul Halpern, A Naval History of World War I (Annapolis: US Naval Institute Press, 1994), 372.

77 Halpern, 67; Pattee, 61-2.

78 Wikepedia.de, Hilflskreuzer Prinz Eitel Friedrich; accessed 10 February 2019; Hugo von
} 
in South and Central American ports at the outbreak of war. ${ }^{79}$ Commander James' summaries include reports about German merchant ships thought to be about to break out of harbour and of others transferred to American registry but suspected of planning to carry contraband cargo to Europe. ${ }^{80}$ They also contain speculation that, contrary to the Admiralty's conclusions, as early as February 1915 that certain merchant ships might mount guns and break out.

\section{Maintaining the Blockade}

Steam-powered vessels still overwhelmingly burned coal ${ }^{81}$ The Admiralty had a global network of coaling depots including Esquimalt and Halifax. ${ }^{82}$ The RN had found Welsh semi-bituminous coal far superior to coal from other sources. It burned more efficiently, produced less smoke and ash, and did less damage to furnaces ${ }^{83}$ The Fleet Coaling Service controlled over 300 colliers, a portion of which was constantly transporting Welsh coal around the world to coaling stations including Esquimalt and to rendezvous locations with deployed warships. ${ }^{84}$ There was a coaling pier in the dockyard where the fuel was still loaded manually. Vancouver Island coal was an important local source; when Welsh coal was not available merchant vessels and warships loaded the fuel in Union Bay south of Courtenay on the eastern side of the island, a convenient location for cargo ships coming out of Vancouver to start their ocean voyages. The very first weekly report prepared by Commander James in August 1914 started with a summary of available coal stocks

\footnotetext{
Waldeyer-Harz, Der Kreuzerkrieg 1914-1918 (Oldenburg: Gerhard Stalling, 1931), 18, 168. Prinz Eitel Friedrich had been armed at the German base in Tsingtau. She remained at large for seven months, eventually captured three Allied merchant ships in the eastern Pacific and eight in the Atlantic. It's noteworthy that eight of her captures were sailing vessels. Her limitations as a thinskinned former liner meant avoiding areas where enemy warships might be expected such as the target-rich focal area off the Plate. Prinz Eitel Friedrich, low on coal, finished her cruise in Newport News where she requested internment. Interestingly she was pursued into port in March 1915 by Canada's east coast cruiser HMCS Niobe.

79 Wikepedia.de, Deutsche Dampfschiffahrtsgesellschaft Kosmos; SS Amasis. accessed 15 April 2019.

${ }^{80}$ Saxonia, a small German freighter lying in Seattle, was reportedly under surveillance by consular staff and a special agent. Weekly ROP, Weeks of 30 October 1914, 15 January, 12 March 1915.

${ }^{81}$ Almost 90 percent of the world's merchant fleet used coal. A small portion, 2.62 percent, had boilers that could burn oil or coal and only 0.47 percent used oil alone. Just under 8 percent were still sail powered. Joseph Zeller "British Maritime Coal and Commercial Control in the First World War: Far More Than Mere Blockade," Canadian Military History 24:2, 41; Joseph Zeller, "Coal: A Significant Factor in Germany's Defeat in Word War I," Canadian Military History 27:1, 7.

82 Gray, op. cit., is a recent study of the worldwide system.

${ }^{83}$ James Goldrick, "Coal and the Advent of the First World War at Sea," War in History, 21:3 (2014), 322-337. It's extraordinary that as Goldrick shows forty collieries in a section of the Welsh coal fields produced the best coal in the world.

${ }^{84}$ A Handbook of Instructions to Officers and Others in H.M. Dockyards at Home as to Duties and Accounts Relating to Naval Stores and to the Fleet Coaling Service (London: HMSO, 1909), 213; Fayle, 2:176 shows 325 colliers allocated to Fleet Service as of 1 October 1915: ten were "allocated to Mediterranean and Foreign Stations and twenty-six "to be allocated."
} 
and sources and included an inventory of colliers. Colliers coming to Esquimalt transported timber and other cargoes back to Britain.

The cruisers and AMCs in the Pacific were technologically rugged and proved able to operate for months without dockyard support. Although its facilities were limited Esquimalt provided essential deep maintenance and logistic depth. All but one of the seven warships and AMCs that operated for extended periods in the eastern Pacific between 1914 and 1918 came to Esquimalt for maintenance. Its remoteness from the South American coast underlined the challenges caused by long distances in the Pacific. The logbooks show that the passage to and from the northern end of the South American operational area took about three weeks at economical speed. The most complicated repairs involved Newcastle. She was one of a large class of modern cruisers which were the first to be powered by steam turbines. One of her engines developed a problem in early 1915. Fortuitously Edward Izard of Yarrows had turbine experience in Scotland and now supervised the first turbine repair in Canada in March 1915. The armoured cruiser Kent, which had been in the Battle off the Falklands the previous November and subsequently in the successful hunt off Chile in March 1915 for Dresden, came north in May to refit and have battle damage repaired. In the following year Newcastle required extensive boiler work between May and August. Her boilers had been manufactured by Yarrows in Scotland who sent twelve skilled boilermakers out along with a large newly manufactured special wrapper plate. ${ }^{85}$

Esquimalt supported the Japanese warships that operated in the eastern Pacific early in the war. Idzumo was in the area for several months starting in August 1914, receiving various minor repairs by Yarrows ${ }^{86}$ A second armoured cruiser Asama while investigating Mexican waters for German merchant ships grounded off Magdalena Bay in January 1915. Damage was serious. The Japanese Navy organized a major salvage effort, bringing shipwrights and a repair ship from Yokosuka. Some supplies were marshalled in Esquimalt and transported forward.$^{87}$ After four months of repairs Asama came to Esquimalt for seven weeks of further work by Yarrows. ${ }^{88}$

Yarrows also manufactured items for the Imperial Munitions Board, Canadian Explosives Ltd and the US Emergency Corporation. These included shell casings, large propellers, and high-pressure cylinders, some as large as eight tons. ${ }^{89}$ By 1918 it had 800 employees. During the war years Yarrows repaired and overhauled several merchant ships. In 1918 the firm was involved in fitting machinery in

\footnotetext{
85 "EW Izard History Project Yarrows" MMBC L 984.6.1a. Izard noted that during sea trials on completion of the turbine repairs Newcastle achieved higher speeds than during her builder's trials.

86 Izard; Japanese payments received by the Dockyard were credited to the imperial government which underlines how it was functioning as part of the global imperial war effort. "Note to Chief Accountant," LAC RG 2411902 D-11 Vol 11902 file AE 6-10-3 "Visit HIJMS Idzumo."

${ }^{87}$ George Phillips, "Canada's Naval Part in the War" (1919), MMBC ACC 2017: 985.38.12.

${ }_{88}$ Commemorative Album in Japanese titled Battleship Asama. Its Cruise to the War Front was published in December 1915; MMBC ACC 2017: 985.38.80.

${ }^{89}$ Weekly ROP Week ending 14 September 1918, annotated "History Project Yarrows"
} 
small wooden freighters that had been built in Victoria harbour for the Imperial Munitions Board.

At a time before good ani-fouling paints and cathodic protection to control corrosion had been developed for ships' hulls, it was estimated that by the end of a year progressive underwater fouling would require the use of 50 percent more power to achieve a given speed..$^{90}$ Small wonder that the logbooks show that the cruisers had divers who were frequently over the side to clean the hull between dockings; these were also loaned to AMCs. The cruisers and AMCs in the Pacific were drydocked yearly to have their hulls cleaned, new underwater paint applied, and other work. The Victorian graving dock in Esquimalt proved large enough only for Newcastle which used it in 1914, 1915, and $1916^{91}$ but not for the AMCs, Kent and Lancaster. Using US graving docks would have contravened the Hague Convention of 1907 which specified that belligerent warships were not to remain in neutral waters for more than twenty-four hours (Article 12) and were permitted only repairs "absolutely necessary to render them seaworthy" (Article 17). ${ }^{92}$ The first AMC to require periodic docking was HMS Orama which had been at sea since August 1914. She refitted at the Cockatoo Dockyard in Sydney NSW in August 1915 and was followed by Otranto in early $1916 . .^{3}$ The British and Chilean navies had a long association and in 1915 notwithstanding the Hague Convention HMS Kent was drydocked in the Chilean naval dockyard at Talcahuano, Chile, ${ }^{94}$ 21-30 August, after refitting in Esquimalt 24 May-8 July. ${ }^{95}$ The newly-completed wooden floating drydock in Prince Rupert was first used by the AMC Orbita in late 1916 after she had grounded off Colombia. Yarrows and the dockyard sent workers north because the dry dock lacked repair crews. ${ }^{96}$ It was subsequently used by three AMCs and Lancaster. On completion of five weeks of repairs in Prince Rupert during which her captain had been replaced after the 1916 grounding, Orbita had reported "repairs satisfactory, permanent for duration of war." 97 Unfortunately, Orbita grounded again off Port Monti in southern Chile in August 1917. She then spent seven days anchored off Talcahuano while Chilean naval dockyard fitters did repairs and subsequently spent two months in a US Navy graving dock at

\footnotetext{
${ }^{90}$ David K Brown, Warrior to Dreadnought: Warship Design and Development 1860-1905 (Barnsley: Seaforth, 2010), 158

${ }^{91}$ Newcastle's length was $138 \mathrm{~m}$, that of the dock $146 \mathrm{~m}$.

92 Rights and Duties of Neutral Powers in Naval War (Hague, XIII, available on the web under https://avalo.law.yale.eduhague15, accessed 20 March 2019.

${ }^{93}$ Cockatoo Island had a $193.5 \mathrm{~m}$ (635 feet) dock completed in 1890.

${ }^{94}$ Britain had developed strong relationships with most of South America in the nineteenth century and until just prior to 1914 was still its leading trading partner and source of foreign capital. The graving dock was completed in 1895 , length $175 \mathrm{~m}$ (574 feet), and is still in use.

${ }^{95}$ HMS Kent Report of Proceedings 31 August 1915 TNA ADM 137/762, 169-171. While docking was required to repair a defective stern tube bearing it also enabled bottom cleaning.

96 Weekly ROP Week ending 5 December 1916. When this new dock was completed in late 1915 war had disrupted anticipated trade; it was used during the conflict only by naval vessels. GW Taylor, 148.

${ }^{97}$ Weekly ROP Week ending 5 December 1916.
} 
Mare Island on San Francisco Bay at the end of the year. ${ }^{98}$ (Once the United States entered the war American graving docks had become available.) Avoca, docked in Prince Rupert in early 1917, but went to Mare Island in 1918, and Lancaster was drydocked in Bremerton on Puget Sound in February 1919.

\section{Intelligence Reporting}

The weekly reports show that much information came from British consular staff and newspaper clippings but "Secret Agents" had also been established in some US ports. ${ }^{99}$ Pinkerton agents were also working for the British in Seattle. ${ }^{100}$ The Seattle Pinkerton agent complained in December 1915 that it was difficult to obtain information without paying for it, particularly as the German Consul had "unlimited funds." ${ }^{101}$ Commander James also met frequently with the Military District Intelligence Officer. The Victoria postmaster passed on alarming information based on reading mail about German plots to attack docks etc. ${ }^{102}$ The Canadian government had imposed draconian rules in the interests of trying to control news coverage and opinions considered undesirable, eventually prohibiting the possession of 250 publications, mostly originating in the US. ${ }^{103}$ Commander James therefore also received information from the postmaster about proscribed publications, such as a report in August 1915 about a banned newspaper addressed to an individual in Langford outside Victoria. ${ }^{104}$

The contemporary documents reflect a high degree of concern about enemy spies and sabotage. An internment camp was opened in Nanaimo early in the war to accommodate foreign-born people believed to be potentially dangerous or judged to be acting suspiciously; it was closed in September 1915 and operations consolidated in a camp in Vernon. ${ }^{105}$ Many of the reports on suspicious activities in Commander James' records proved unsubstantiated. However, acts of sabotage,

\footnotetext{
98 Weekly ROP Week ending 15 December 1916; Orbita logbooks 13 August; 27 August - 5 September; 30 October - 26 December 1917. The log records strong tidal currents in the Chacao Narrows where Orbita was aground forward for over five hours. No details are given about the damage. Commander Hugh Percival Buckle, who had been in command since November 1916 was cautioned to be more careful after the grounding; when Orbita sank a collier in February 1918 he incurred "their Lordships' displeasure." HMS Orbita (1914)" and "Hugh Percival Buckle" at www. dreadnoughtproject.org accessed 15 January 2019

99 Unsigned letter from Cdr James 9 September 1915, MMBC ACC 2017.001 ARC 51 General Subjects: A Jones Reports: Cdr James had apparently shown Premier McBride the sort of reporting that could be expected from a Mr. Alleyne Jones, who had just been appointed Secret Agent Seattle. The correspondence refers to other secret agents in Puget Sound ports.

100 Weekly ROP, Week ending 5 February 1915.

101 Weekly ROP, Week ending 24 December 1915.

102 Weekly ROP, Weeks ending 27 September 1917 and 24 June 1918.

103 Brock Millman Polarity, Patriotism, and Dissent in Great War Canada, 1914-1919 (Toronto: University of Toronto Press, 2016), 29; "Revised List of Publications, the Possession of Which in Canada is Prohibited," MMBC ACC 2017.001.

${ }^{104}$ Weekly ROP, Week ending 27 August 1915.

${ }^{105}$ Weekly ROP, Week ending 5 November 1914 and 1 October 1915
} 
including an attempt to damage the Welland Canal in Ontario, were in fact carried out by Central Powers agents in the US. Whether the report in April 1915 by the consul in Seattle on an attack planned on the CPR docks in Vancouver by four men hired by the "German Irish Society" in his city was based on solid intelligence is unknown, but authorities were alerted. ${ }^{106}$ Finally, the reports included surveillance that reads like popular novels or newspaper stories of females suspected of vaguely suspicious activities. ${ }^{107}$

\section{Conclusions}

The Canadian west coast played a role that has been overlooked in Britain's successful global economic campaign against the Central Powers. The blockading operations of cruisers and armed merchant cruisers in the eastern Pacific between 1914 and 1918 reflect the maritime dimension of this global conflict. Esquimalt served as their base. Its Naval Intelligence Centre acted as a cog in the Admiralty's global system for gathering information essential for effective economic warfare. Established as an imperial outpost in the 1860s Esquimalt functioned as such during the Great War. Yarrows shipyard, adjacent to the dockyard, repaired both warships and merchant ships vital to the Allies, particularly when the unanticipated success of German submarines in the North Atlantic put shipping resources under severe strain.

Both the British and the Germans had created organizations before the war to support economic warfare in the Pacific. Both sides proved resourceful in marshalling afloat logistics. Contrary to British pre-war fears, Germany was only able to operate a mere handful of ships against commerce worldwide, causing just temporary disruptions of Allied shipping. RN vessels maintained an unrelenting presence close offshore along 2,400 $\mathrm{nm}(4,444 \mathrm{~km})$ of coastline from Ecuador to Chile for four years to confine the enemy merchant ships in South and Central American ports. The blockading ships were either underway or at anchor; periodic

\footnotetext{
106 Weekly ROP, Week ending 16 April1915.

${ }^{107}$ A February 1916 report from Tacoma was the first in a series about a Mrs. Jennie Rawak, thought to be wealthy, who had been in France at the outbreak of war, "was accused of being active in Germany's interests" and was now travelling across the Pacific from Vancouver. Cdr James obtained departmental approval to hire a private detective to watch Mrs. Rawak while she was in Hawaii where she had apparently met with the German Consul. She was described as "short, dark, aged about 45, small dark eyes, sallow complexion and distinctly Jewish appearance." The reports end when Mrs. Rawak sailed for Japan on 16 April. Weekly Intelligence Reports, Weeks ending 11 February , 17 March, 1 and 21 April 1915. In June 1917 the Consul General San Francisco reported on a Miss Inga Rhode, a passenger voyaging from San Diego to Yokohama via Seattle and Vancouver. "An Englishwoman sharing her cabin went through her correspondence" which revealed that she had letters from a firm with a German name in Yokohama and had been told to call herself Miss Jones in Seattle and to stay at the Empress in Victoria. Cdr James informed the local District Intelligence Officer, Customs in Victoria, and Hong Kong. The District Intelligence Officer subsequently investigated: "nothing suspicious was found and Miss Rhode was allowed to proceed." Weekly ROP, Weeks ending 22 and 29 June 1917.
} 
maintenance and crew rest were carried out at Esquimalt, three weeks' steaming each way from the patrol areas. The logistical challenges involved in supporting a continuous presence of four large naval vessels were formidable. The cruisers required coal every ten days and the AMCs monthly. They were replenished largely from colliers sent out from the UK that also transported provisions and stores; fresh foodstuffs were provided by commercial lighters off major ports. The Victorian graving dock at Esquimalt proved too small for all but one of the seven cruisers and AMCs but the new floating drydock in Prince Rupert, and graving docks in Sydney, NSW and, after 1917, in US naval bases were utilized.

The dawn of rapid worldwide connections through the new technologies of radio and worldwide cable networks enabled the Admiralty to control operations in the eastern Pacific. These new

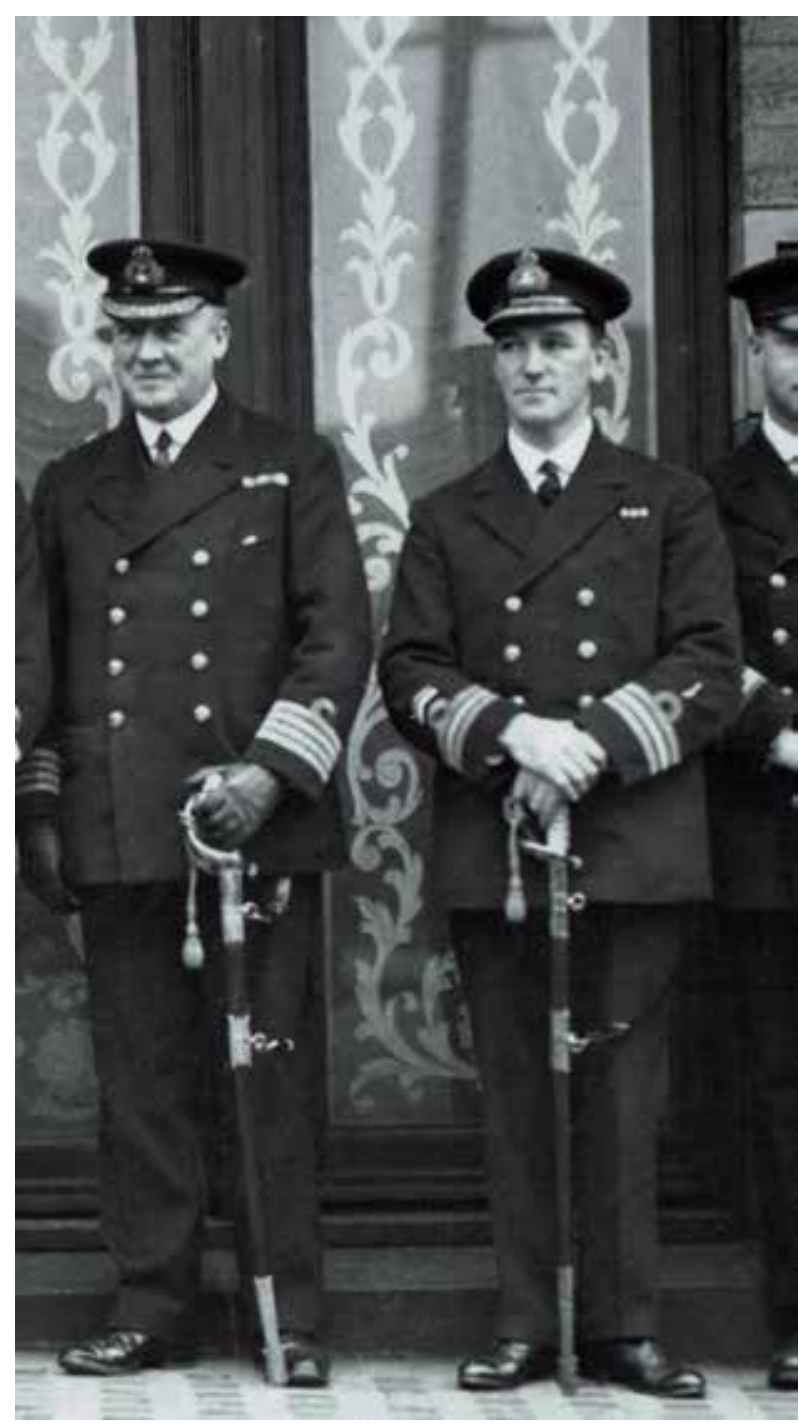

Two of the former Royal Navy Officers who took the strain on the West Coast: Captain Edward Martin, Captain

Superintendent Esquimalt 1918-19 and Commander Frederic James, Naval Intelligence Officer 1914-19. Note war service chevrons above lace curl on Cdr James' right sleeve. (Maritime technologies also enabled Museum of British Columbia) the Esquimalt Naval Intelligence Centre to gather and pass on intelligence about shipping movements from a network of reporting officers in all major ports on the west coast of North America.

And what of the three RN officers, recently retired and arrived in Canada, in this story? They typified the pool of seasoned individuals who fortuitously were 
available to help the embryonic RCN meet the challenges of 1914-18. Frederic William Haigh James was promoted by the RN to the rank of captain in recognition for his wartime service. He initially returned to England, but then settled in Victoria. In 1939, aged seventy-four, he volunteered his services again but was considered too old. He died at the age of ninety-three in 1958. Admiral Story, promoted to the rank of vice admiral in May 1917, was transferred to Halifax in February 1918 when the growing Atlantic war required a more senior Canadian presence on that coast. He exchanged positions with Captain Edward H Martin who had been the superintendent of the Halifax Dockyard since $1910 .{ }^{108}$ William Story was promoted again by the RN to the rank of admiral on retirement in 1919 . He travelled extensively across Canada inspecting Navy League Sea Cadets corps as their supervisor after the war and died in 1938 at the age of seventy-nine. Edward Harington Martin retired in 1920. He died in Yokohama in 1921, aged sixty-one while travelling to India where he had served during his naval career.

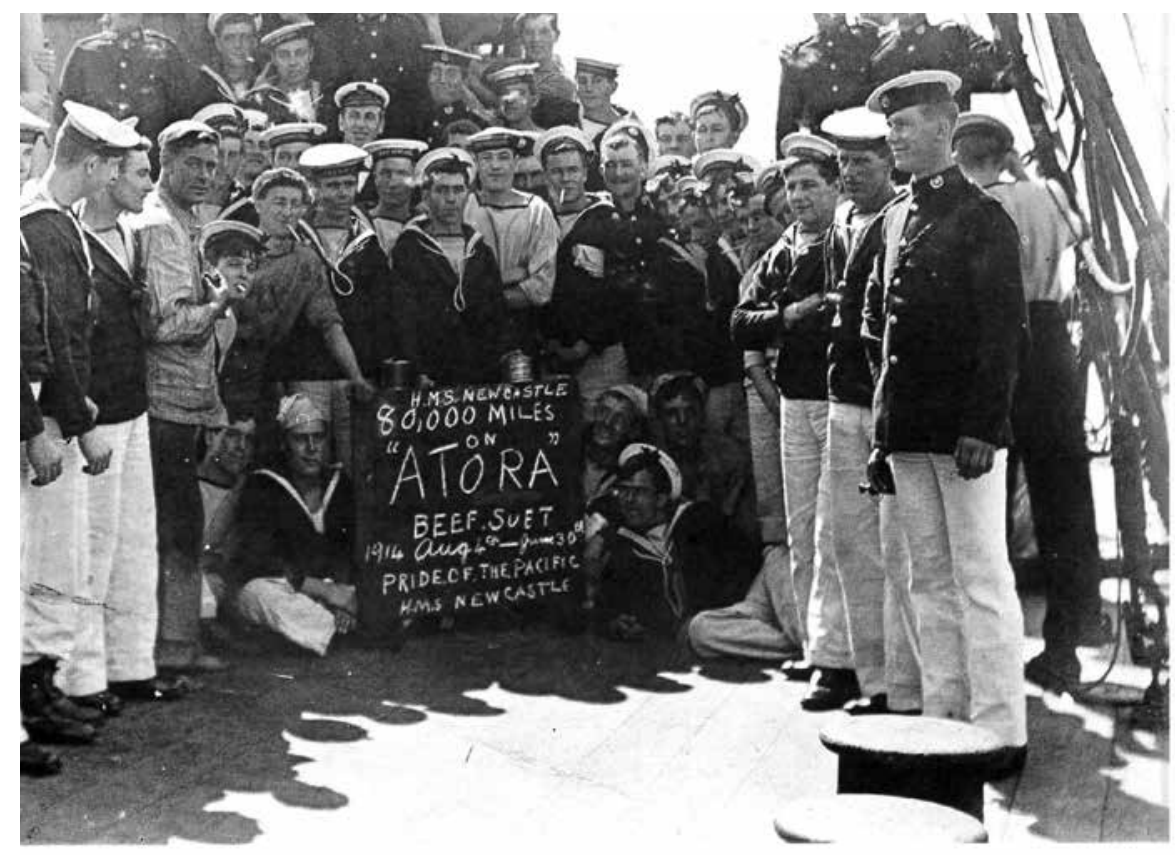

Brand Promotion 1914: Crew members of HMS Newcastle including Royal Marines (figures on right \& in background) posing with sign Advertising "ATORA" brand beef suet. Newcastle arrived in Esquimalt in August from the China Station and remained in the eastern Pacific for two years. (Maritime Museum of British Columbia)

${ }^{108}$ Edward Harington Martin, born in 1860, applied to Rear Admiral Kingsmill in 1910 after retiring in the rank of commander after a thirty-seven year career in the $\mathrm{RN}$ for a position in the newly created RCN; he had served in Halifax since coming to Canada in 1910, initially as the Commander-inCharge. 